\title{
Analisis Kinerja Sumber Daya Aparatur Unit Pelaksana Teknis Balai Latihan Kerja Pasuruan dalam Melaksanakan Pelatihan Keterampilan (Studi Kasus pada Unit Pelaksana Teknis Balai Latihan Kerja Pasuruan Dinas Tenaga Kerja dan Transmigrasi Provinsi Jawa Timur)
}

\author{
Imarotus Shohiya Multazima ${ }^{1}, A^{\prime}$ an Warul Ulum ${ }^{2}$ \\ ${ }^{1,2}$ Program Studi Administrasi Publik, Universtas Yudharta Pasuruan \\ Email: immultazima@gmail.com
}

\begin{abstract}
Developing countries are often faced with large numbers of unemployed people because of their relatively large population. Unemployment is a serious problem for the country considering the risks that also have an impact on the economy and social conditions of a country. One of the things that can be done is job training. Vocational Training Centers are training facilities and infrastructure to obtain skills training in certain fields so that graduates have skills and competitiveness in the job market or Entrepreneurial. Organizational continuity can be seen and determined from its success in achieving a goal. Therefore, the performance or performance organizationalis important to know well. The research method used in this research is qualitative research with a descriptive approach. This study uses performance indicators from Wibowo (2016). There are seven indicators according to Wibowo (2016), objectives, standards, feedback, tools or facilities, competencies, motives, and opportunities. Based on the results of the research and discussion that has been described, it can be concluded that the performance of UPT BLK in the implementation of job training has gone well, although from several indicators it still needs additional or improved performance.
\end{abstract}

Keywords: Performance, Human Resource, Training Center

\begin{abstract}
Abstrak. Negara berkembang seringkali dihadapkan dengan besarnya angka pengangguran karena jumlah penduduknya yang tergolong besar. Pengangguran menjadi persoalan yang serius bagi negara mengingat resikonya yang juga berdampak terhadap ekonomi dan sosial suatu Negara. Salah satu hal yang dapat dilakukan adalah pelatihan kerja. Balai Latihan Kerja adalah sarana dan prasarana pelatihan untuk mendapatkan pelatihanketerampilan di bidang tertentu agar lulusan memiliki keterampilan serta daya saing di pasar kerja atau usaha mandiri. Kelangsungan organisasi dapat dilihat dan ditentukan dari keberhasilannya mencapai sebuah tujuan. Maka dari itu kinerja atau performance organisasi merupakan hal yang penting untuk diketahui dengan baik.Metode penelitian yang digunakan dalam penelitian ini adalah penelitian kualitatif dengan pendekatan deskriptif. Penelitian ini menggunakan indikator kinerja dari Wibowo yaitu tujuan, standar, umpan balik, alat atau sarana, kompetensi, motif, dan peluang. Berdasarkan hasil penelitian dan pembahasan yang telah diuraikan maka dapat disimpulkan kinerja UPT BLK dalam pelaksanaan pelatihan kerja sudah berjalan dengan baik meskipun dari beberapa indikator masih perlu penambahan atau perbaikan kinerja.
\end{abstract}

Kata Kunci: Kinerja, Sumber Daya Manusia, Balai Latihan Kerja

\section{PENDAHULUAN}

Negara berkembang seringkali dihadapkan dengan besarnya angka pengangguran karena jumlah penduduknya yang tergolong besar. Pengangguran menjadi persoalan yang serius bagi negara mengingat resikonya yang juga berdampak terhadap ekonomi dan sosial suatu Negara. Ada banyak faktor yang menyebabkan terjadinya pengangguran. Misal sulitnya berinvestasi menjadikan salah satu penyebab minimnya lapangan pekerjaan. Pengangguran di setiap negara berdampak terhadap pertumbuhan ekonomi. Kurangnya lapangan pekerjaan menjadi salah satu penyebab terjadinya pengangguran. Selain kurangnya lapangan pekerjaan dan rendahnya kualitas sumber daya manusia yang dimiliki. Inflasi, ledakan penduduk, serta kelangkaan investasi juga menjadi salah satu faktor dalam menambah angka pengangguran. (Franita, 2016).

Agar bisa mengatasi kondisi tersebut maka diperlukan solusi dan upaya-upaya yang tepat yang dapat mengarah kepada kesempatan kerja. Salah satunya adalah penggunaan tenaga kerja dengan meningkatkan keterampilan tenaga kerja. Salah satu hal yang dapat dilakukan adalah pelatihan kerja 
melalui Balai Latihan Kerja. Balai Latihan Kerja adalah sarana dan prasarana pelatihan untuk mendapatkan pelatihan keterampilan di bidang tertentu agar lulusan memiliki keterampilan serta daya saing di pasar kerja atau usaha mandiri.

Balai Latihan Kerja merupakan organisasi sektor publik. Menurut Irianto (2012:5) sektor publik memiliki karakteristik tertentu yang tidak melekat dalam sektor privat yaitu tidak berorientasi pada perolehan keuntungan (profit) namun pada kepentingan masyarakat serta dimiliki oleh pemerintah dan bukan merupakan kepemilikan pribadi.

Pelatihan yang dilaksanakan diarahkan untuk meningkatkan kemampuan sumber daya manusia agar sesuai dengan kesempatan kerja dan tuntutan kerja yang tersedia di pasar kerja. Pelatihan sendiri adalah bagian dari pendidikan diluar sekolah. Memasuki era pasar kerja yang banyak persaingan diantaranya adalah berkaitan dengan skill yang memadai. Hal ini dapat menjadi perhatian khusus bagi para calon tenaga kerja untuk meningkatkan skill atau keahliannya di bidang atau keterampilan tertentu agar dapat mendapatkan tempat yang sesuai ketika berhadapan dengan dunia kerja.

Pelatihan kerja yang tidak sesuai dengan kebutuhan pasar tenaga kerja akan berdampak kepada bertambahnya pengangguran.Ketidakseimbangan antara pencari kerja dan lapangan pekerjaan adalah salah satu hal yang harus dicari jalan keluarnya. UPT Balai Latihan Kerja Pasuruan Dinas Tenaga Kerja dan Transmigrasi Provinsi Jawa Timur adalah salah satu lembaga yang menangani persoalan pelatihan kerja bagi para pencari kerja. UPT Balai Latihan Kerja Pasuruan ini adalah salah satu institusi di Kabupaten Pasuruan yang melaksanakan pelatihan kerja di wilayah Provinsi Jawa Timur.

Tingkat kepercayaan yang baik dari masyarakat terhadap UPT BLK Pasuruan menjadikan UPT BLK Pasuruan sebagai Balai Latihan Kerja yang banyak peminatnya. Hal inidapat dilihat dari jumlahrealisasi pelatihan dan penempatandengan total yang cukup banyak. Dari data yang diperoleh berikut realisasi pelatihan dan penempatan pada tahun 2017 hingga tahun 2020.

Tabel 1. Rekap Realisasi dan Penempatan

\begin{tabular}{|c|c|c|c|c|}
\hline \multirow{2}{*}{ No } & \multirow{2}{*}{ Tahun } & Jumlah & \multicolumn{2}{|c|}{ Penempatan } \\
\cline { 4 - 5 } & & Lulusan & Industri & Wirausaha \\
\hline 1 & 2017 & 1.168 & 618 & 299 \\
\hline 2 & 2018 & 2.208 & 874 & 810 \\
\hline 3 & 2019 & 2.183 & 611 & 742 \\
\hline 4 & 2020 & 102 & 32 & 69 \\
\hline
\end{tabular}

Kelangsungan organisasi dapat dilihat dan ditentukan dari keberhasilannya mencapai sebuah tujuan. Maka dari itu kinerja atau performance organisasi merupakan hal yang penting untuk diketahui dengan baik. Dari adanya kinerja organisasi dapat diketahui tingkat keberhasilan suatu organisasi dalam mencapai tujuannya. Kinerja organisasi juga dapat didukung dengan sumber daya manusia yang memadai. Hal ini bisa dilihat dari pegawai yang memiliki sertifikasi kompetensi dari Lembaga Sertifikasi Profesi Badan Nasional Sertifikasi Profesi atau LSP BNSP dan lain sebagainya.

Informasi mengenai kinerja organisasi dapat berguna untuk evaluasi apakah dalamimplementasinya program kegiatan sudah berjalan dengan baik sesuai dengan tujuan yang diharapkan. Pengertian kinerja atau performance merupakan gambaran mengenai tingkat pencapaian pelaksanaan suatu program kegiatan atau kebijakan dalam mewujudkan sasaran, tujuan, visi dan misi organisasi yang dituangkan melalui perencanaan strategis suatu organisasi. (Moeheriono, 2014:95)

Kinerja (performance) adalah gambaran mengenai tingkat pencapaian pelaksanaan suatu kegiatan/program/kebijakan dalam mewujudkan sasaran, tujuan, misi dan visi organisasi yang tertuang dalam strategic planning suatu organisasi. Istilah kinerja sering digunakan 
untuk menyebut prestasi atau tingkat keberhasilan individu maupun kelompok individu (Mahsun 2016:25).

\begin{tabular}{lccccccccr}
\multicolumn{2}{c}{ Menurut } & Veithzal Rivai SDM adalah seorang yang siap, mau dan & dan \\
mampu & memberi & sumbangan usaha pencapaian tujuan organisasi. Selain itu \\
sumber & daya & manusia & merupakan salah satu unsur masukan & (input) yang \\
bersama & unsur & lainnya & seperti modal, bahan, mesin dan metode/teknologi \\
diubah & menjadi proses manajemen menjadi keluaran (output) berupa barang
\end{tabular}
atau jasa dalam usaha mencapai tujuan perusahaan. Penelitian ini menggunakan indikator kinerja dari Wibowo (2016). Terdapat tujuh indikator menurut Wibowo (2016) yaitu tujuan, standar, umpan balik, alat atau sarana, kompetensi, motif, dan peluang.

\section{METODE PENELITIAN}

Jenis penelitian yang digunakan dalam penelitian ini adalah penelitian kualitatif dengan pendekatan deskriptif. Metode kualitatif ini digunakan guna dapat mendalami bagaimana kinerja UPT BLK dalam melaksanakan pelatihan. Data yang digunakan dalam penelitian ini berasal dari dua sumber. Yaitu data primer dan data sekunder. Teknik dan alat pengumpulan data yang digunakan peneliti dalam penelitian ini adalah observasi dan wawancara.

Observasi adalah bagian dari teknik pengumpulan data. Melakukan observasi yakni melakukan pengambilan data secara langsung di lapangan. Yang artinya peneliti berada bersama partisipan. Wawancara adalah bagian dari teknik pengumpulan data. Wawancara dilakukan dengan mengajukan pertanyaan-pertanyaan kepada partisipan guna mendapatkan pengertian terhadap apa yang akan diteliti. Dokumentasi adalah bagian dari teknik pengumpulan data dengan mendokumentasikan material tertulis.

\section{HASIL DAN PEMBAHASAN}

UPT BLK Pasuruan memiliki tujuan yang tertera dalam visi dan misi organisasi. Kinerja yang dihasilkan menuju ke arah tujuan yang ingin dicapai. Menjadikan Lembaga Pelatihan Kerja Yang Terpercaya dan Berdaya Saing diEra Global adalah visi dari UPT BLK Pasuruan. Dari visi inilah UPT BLK memberikan pelayanan kepada masyarakat dengan sebaik mungkin. Masa pandemi Covid-19 saat ini UPT BLK Pasuruan mengadakan pelatihan menyesuaikan paket pelatihan yang sedang dibutuhkan masyarakat di era pandemi. Dari permasalahan di masa pandemi saat ini menyebabkan banyak terjadi rasionalisasi, perusahaan yang tutup yang berimbas pada PHK karyawan sehingga menyebabkan dampak bagi ketenagakerjaan. Sehingga dari permasalahan ini UPT BLK memberikan paket-paket pelatihan yang disesuaikan dengan pasar kerja di tahun berikutnya di 2021.

Dalam menyelenggarakan pelatihan hingga sertifikasi, standar kinerja UPT BLK Pasuruan tergolong baik. Dilihat dari proses awal pendaftaran hingga sertifikasi dan pembuatan laporan yang tidak berbelit-belit. Meskipun dalam beberapa administrasi membutuhkan ketelitian. Seperti pembuatan laporan yang terkadang terjadi kesalahan atau tertukarnya data-data atau hilangnya data.

Umpan balik atau feedback yang peneliti ambil adalah umpan balik secara horizontal. Yaitu umpan balik atau feedback dari masyarakat. UPT BLK Pasuruan memiliki feedback yang baik dari masyarakat.Dilihat dari antusias masyarakat dalam mengikuti pelatihan. Tetapi masih terdapat kekurangan dalam pelayanan yang memadai dikarenakan masa pandemi yang menyebabkan sebagian pegawai Work From Home sehingga pelayanan langsung kepada masyarakat baik calon peserta pelatihan maupun alumni berjalan kurang maksimal.

Alat atau sarana adalah salah satu hal yang patut dipenuhi agar dapat meningkatkan kinerja organisasi. Alat atau sarana di UPT BLK Pasuruan tegolong menunjang kegiatan. Baik itu hal yang berkaitan dengan kegiatan administrasi, workshop, pembukaan/penutupan pelatihan, proses pemberian sertifikasi dan lain sebagainya. Kompetensi SDM aparatur di UPT BLK dirasa cukup baik. Meskipun didukung data yang diperolehhanya sebagian instruktur maupun pegawai yang memperoleh sertifikasi dari Lembaga Sertifikasi Profesi atau LSP BNSP.

Motif ada yang berasal dari internal dan juga eksternal. Disebut juga dengan motif intrinsik yaitu motif yang berasal dari dalam dan motif ekstrinsik yaitu motif yang berasal dari luar. Motif- 
motif ekstrinsik yang ada berdasarkan budaya organisasi yang baik, berdasarkan tujuan bersama dan visi misi organisasi.Namun untuk fasilitas motivasi yang berasal dari kepemimpinan dirasa masih kurang.

Semua orang dalam organisasi berpeluang untuk berprestasi. Pegawai UPT BLK menunjukkan prestasi kerjanya dengan hasil kerja yang telah dilakukan selama melakukan pelatihan. Capaian telaksananya sebuah program juga merupakan sebuah prestasi dari kinerja pegawai. Hal ini merupakan peluang atau kesempatan untuk menunjukkan prestasi kerja pegawai baik kepada pimpinan maupun kepada masyarakat.

\section{PENUTUP}

Berdasarkan hasil penelitian dan pembahasan yang telah diuraikan maka dapat disimpulkan kinerja UPT BLK dalam pelaksanaan pelatihan kerja sudah berjalan dengan baik meskipun dari beberapa indikator masih perlu penambahan atau perbaikan. Hasil yang kurang baik dapat diketahui dari kurang maksimalnya kinerja di tengah pandemi. Hasil mengenai kinerja UPT BLK diukur melalui 7 indikator yang terdiri dari tujuan, standar, umpan balik, alat atau sarana, kompetensi, motif dan peluang.

Dari indikator kinerja yang telah dijelaskan maka peneliti memberikan saran bahwasannya dari standar kinerja yang ada di Balai Latihan Kerja sudah berjalan dengan baik. Untuk kelangsungan administrasi data-data yang diperlukan diarsipkan dengan lebih baik. Serta dari pimpinan organisasi untuk lebih memberikan motivasi kepada pegawai agar suasana pelatihan lebih bersemangat dan melahirkan dorongan-dorongan yang positif guna kesinambungan dan kelancaran tujuan organisasi.

\section{UCAPAN TERIMA KASIH}

Peneliti menyadari penelitian ini tidak akan selesai tanpa doa, dukungan dan dorongan dari berbagai pihak. Dalam kesempatan ini peneliti ingin mengucapkan banyak terima kasih kepada Bapak A'an Warul Ulum, S.Pd, M.KP selaku dosen pembimbing. Tak lupa kepada pimpinan UPT Balai Latihan Kerja Pasuruan Bapak Setijo Budi, M.Si dan segenap pihak UPT BLK Pasuruan yang telah berkenan memberikan waktu dan tempat kepada kami untuk dapat melaksanakan program Praktik Kerja Nyata (PKN) di UPT BLK Pasuruan ini.

\section{DAFTAR PUSTAKA}

Franita, R. (2016). ANALISA PENGANGGURAN DI INDONESIA. Jurnal Ilmu Pengetahuan Sosial.

Irianto, J. (2012). Manajemen Sumber Daya Manusia Sektor Publik. Surabaya: PT Revka Petra Media.

Masun, M. (2016). Pengukuran Kinerja Sektor Publik. Yogyakarta: BPFE-YOGYAKARTA.

Moeheriono. (2014). Pengukuran Kinerja Berbasis Kompetensi. Jakarta: PT RajaGrafindo Persada.

Raco, J. R. (2010). Metode Penelitian Kualitatif. Jakarta: PT Gramedia Widiasarana Indonesia.

Wibowo. (2016). Manajemen Kinerja. Jakarta: PT RajaGrafindo Persada. 